\title{
Relapsing polychondritis: a review
}

\author{
Aman Sharma • Karthik Gnanapandithan • \\ Kusum Sharma $\cdot$ Susmita Sharma
}

Received: 14 June 2013 / Accepted: 26 June 2013 / Published online: 26 July 2013

(C) Clinical Rheumatology 2013

\begin{abstract}
Relapsing polychondritis is a rare multisystem disease involving the cartilaginous and proteoglycan rich structures. The spectrum of clinical presentations may vary from intermittent episodes of painful and often disfiguring auricular and nasal chondritis, to occasional organ or even lifethreatening manifestations like airway collapse. There is lack of awareness about this disease due to its rarity. Relapsing polychondritis disease activity index has recently been validated and may help in clinical decision making and research. This article reviews the literature on this disease entity.
\end{abstract}

Keywords Auricular chondritis · Nasal chondritis ·

Polychondritis $\cdot$ Polychondropathia $\cdot$ Relapsing

polychondritis $\cdot$ Relapsing polychondritis disease activity index

Key messages - Relapsing polychondritis is a rare disease affecting the cartilaginous and proteoglycan rich structures.

- It should be suspected whenever there is a multisystem presentation with cartilaginous inflammation like auricular chondritis, nasal chondritis, airway involvement, arthralgias, arthritis and involvement of proteoglycan rich structures like eye.

- Relapsing polychondritis disease activity index is a validated tool for assessment of disease activity

- Institution of therapy may retard the progression of disease manifestations like aortic root dilatation.

\section{A. Sharma $(\square)$}

Department of Internal Medicine, Postgraduate Institute of Medical

Education and Research, Chandigarh 160012, India

e-mail: amansharma74@yahoo.com

K. Gnanapandithan

Department of Internal Medicine, Saint Vincent Hospital,

Worcester, MA, USA

K. Sharma

Department of Medical Microbiology, Postgraduate Institute of

Medical Education and Research, Chandigarh, India

S. Sharma

Department of Obstetrics and Gynaecology, Gian Sagar Medical

College and Hospital, Banur, India

\section{Introduction}

Relapsing polychondritis (RP) is a multisystem disease characterised by recurrent and progressive inflammation of the cartilaginous tissue in various sites of the body. JakschWartenhorst [1] described the first case in literature in 1923 when he used the term "polychondropathia". The term "relapsing polychondritis" was first used by Pearson et al. [2] in 1960 in their review of 12 cases. Since then, a large number of cases have been reported and the knowledge on the clinical spectrum, pathogenesis, and management has been growing considerably.

\section{Epidemiology}

The peak age of onset is the fifth decade of life, with most of the patients between 44 to 51 years at the time of diagnosis [3] though cases have been reported in both the extremes of life. A systematic review of 37 pediatric cases of RP [4] concluded that the childhood form shares the main clinical features of its adult counterpart. Though most studies [5, 6] report an equal sex distribution, Trentham et al. [3], in their study, found a female preponderance of $3: 1$. As most of the data available is on the Caucasian population, the racial distribution of $\mathrm{RP}$ is controversial. Though it appears to be equally prevalent in all racial groups, some series have noted predominance in the white population. In a case series conducted in an Oriental population [7], it was observed that the disease course was similar to that in the Caucasian population except that cutaneous, renal or nervous system involvement was not seen and the incidence of airway complications was more. Another series from North India [8] reported that the clinical features were similar, but laryngotracheal involvement was less frequent in these patients, whereas that from Southern India [9] inferred that auricular and skin involvement were less common. 
Familial or geographical clustering has not been noticed in the studies on RP so far. There is one report [10], of a pregnant woman with RP giving birth to a child with saddle nose deformity and self limiting recurrent arthritis. However, a retrospective study [11] of 25 pregnancies in 11 women with RP inferred that pregnancy does not modify the course of the disease and RP was not observed in any of the neonates.

\section{Etiopathogenesis}

The etiology of RP remains unknown so far. Studies have shown the association of both cellular immunity changes and abnormal autoantibody response in RP.

Cellular immune reactivity towards cartilage extracts has been demonstrated using lymphocyte transformation or macrophage migration inhibition techniques [12]. Buckner et al. [13] described $\mathrm{T}$ cell clones with specificity for peptide corresponding to residues 261-273 of the type II collagen molecule in a patient with RP. Abnormal cellular response to cartilage proteoglycans and imbalance of T lymphocyte subsets has also been described with RP [14].

Both circulating antibodies and immune complex deposits in the affected tissues have been demonstrated in patients with RP. They are generated against native and denatured collagen type II and collagen types IX and XI [15], which form the major extracellular scaffold in the cartilage. Studies $[16,17]$ have shown that $33 \%$ of patients with RP had circulating antibodies to type II collagen in the active phase of the disease and their titres also corresponded to disease activity. Autoimmunity to type II collagen has also been described in systemic lupus erythematosis (SLE) and rheumatoid arthritis, while the epitope specificity of the autoantibodies are different in these conditions $[18,19]$.

HLA class II molecules also seem to be associated with RP. A substantial increase in HLA-DR4 antigen frequency was found [20] in RP as compared to those without the disease though no subtype predominance was noted. Another study [21] of 62 patients concluded that the extent of organ involvement in patients diagnosed with RP was negatively associated with the presence of HLA-DR6. A cellular response directed towards matrillin-I was also demonstrated in these patients [22, 23].

Experimental studies in animal models have confirmed that autoimmunity towards extracellular matrix proteins especially collagen II and matrillin-I can lead to polychondritis closely resembling the clinical picture of RP seen in humans [24, 25].

\section{Clinical features}

The onset of the disease is usually abrupt and there is a characteristic clinical picture. Table 1 summarises the organ involvement in patients with RP in five case series.

\section{Auricular and vestibular involvement}

Auricular chondritis is present in most patients, with inflammation limited to the cartilaginous portion of the pinna and characteristic sparing of the lobule. Pain, discolouration or tenderness of the pinna is the initial symptom in most patients $[26,27]$. The pinna assumes a nodular or verrucous appearance or loses shape and becomes soft and flabby. Auricular collapse, closure of the external auditory meatus, eustachian tube edema or obstruction with serous otitis media can lead to conductive hearing loss. A possibility of stapedial foot plate fixation is also to be considered in these patients as the abnormality is correctable surgically [28]. The hearing loss can also be sensorineural as a result of inflammation of the vestibular structures or vasculitis of the internal auditory artery $[3,5]$. Vestibular dysfunction can also lead to nausea, vomiting, vertigo and ataxia.

\section{Arthropathy}

Joint pain is the second most common clinical feature in patients with RP. It is the initial presenting symptom in $33 \%$ and ultimately is seen in 50 to $75 \%$ [29]. Though any joint may be affected, the metacarpophalangeal, proximal minterphalangeal joints, knees and wrist are most commonly affected. Classically it is an episodic, self-remitting, asymmetric, usually migratory, non-erosive and nondeforming polyarthritis or oligoarthritis with or without synovitis lasting weeks to months.

\section{Nasal chondritis}

Nasal chondritis presents as a sudden onset of pain and tenderness, sometimes with mild epistaxis or serosanguinous exudation [30]. It is present at the time of diagnosis in $24 \%$ and is seen at some stage of the disease in $53 \%$ [27]. The inflammatory process might destroy the nasal cartilage leading to flattening of the nasal bridge or the tip, the former resulting in a saddle nose deformity. Such deformities are more common in patients who are less than 50 years and in females $[3,6]$.

\section{Respiratory tract involvement}

Laryngotracheal involvement by RP is a major cause of morbidity and mortality and is seen in about $50 \%$ of patients. Early symptoms include pain and tenderness over the thyroid cartilage and trachea. Inflammation of cartilages in the larynx and tracheobronchial tree leads to hoarseness of voice, nonproductive cough, dyspnea, stridor and wheezing [5, 31]. 
Table 1 Comparison of clinical features in five case series

\begin{tabular}{|c|c|c|c|c|c|}
\hline & Mc Adam et al. [5] & Michet et al. [6] & Trentham and Le [3] & Kong et al. [7] & Sharma et al. [8] \\
\hline No. of patients & 159 & 112 & 66 & 12 & 10 \\
\hline Mean age at diagnosis & 44 & 51 & 46 & 34 & 49 \\
\hline Female/male & $76: 83$ & $55: 57$ & $49: 17$ & $3: 1$ & $3: 2$ \\
\hline Mean follow-up (months) & NR & 72 & 96 & 96 & 36 \\
\hline Auricular chondritis (\%) & 89 & 85 & 95 & 83 & 100 \\
\hline Reduced hearing (\%) & 46 & 30 & 42 & 17 & 40 \\
\hline Arthritis $(\%)$ & 81 & 52 & 85 & 75 & 80 \\
\hline Saddle nose $(\%)$ & NR & 29 & 20 & 17 & 30 \\
\hline Ocular involvement (\%) & 65 & 51 & 57 & 67 & 50 \\
\hline Laryngotracheal involvement (\%) & 56 & 48 & 67 & 50 & 20 \\
\hline Cardiovascular involvement (\%) & 9 & 6 & 8 & 8 & $10^{\mathrm{a}}$ \\
\hline Skin involvement $(\%)$ & 17 & 28 & 38 & 0 & 30 \\
\hline Tracheostomy (\%) & 6 & NR & 5 & 42 & $10^{\mathrm{a}}$ \\
\hline Death $(\%)$ & 6 & NR & 3 & 0 & $10^{\mathrm{a}}$ \\
\hline
\end{tabular}

$N R$ not recorded

${ }^{\mathrm{a}}$ Only one patient

Complications include destruction of the thyroid cartilage, acute upper airway collapse and obstruction necessitating emergency tracheostomy. Strictures from chronic inflammation are especially common in the subglottic region. Sporadically costochondral cartilage tenderness, dislocation or flial chest can occur. Effectiveness of cough in clearing the secretions is reduced due to airway collapse and inflammation [32]. These respiratory complications, largely tracheal collapse and infections, are the leading cause of mortality in patients with $\mathrm{RP}$ and is reported variedly between 10 and $50 \%[3,6]$.

\section{Cardiovascular disease}

Cardiovascular involvement is seen in 24 to $52 \%$ [33] and is the second most frequent cause of death $[5,6]$ in patients with RP. Vasculitis of any vessel may be seen and the clinical spectrum ranges from cutaneous leukocytoclastic vasculitis to large vessel vasculitis and aneurysmal involvement is most common in the thoracic and abdominal aorta [34]. Kobak et al. [35] described a case of RP with auricular chondritis who had concomitant Takayasu arteritis. Arterial and venous thrombosis in RP may be due to vasculitis or associated antiphospholipid syndrome [36]. Vasculitis in RP may be local or systemic, indolent or fulminant. Valvular heart disease is present in 5 to $10 \%$ of all patients with RP. Aortic regurgitation is seen in 4 to $6 \%$ and mitral regurgitation or mitral valve prolapse in 2 to $4 \%[5,6]$. Rhythm disturbances include incidentally discovered electrocardiographic abnormality, paroxysmal atrial tachycardia, firstdegree heart block and complete heart block [6, 27, 37].
Coronary artery involvement by vasculitis can cause ischemic heart disease. Less commonly reported are myocarditis, pericarditis and silent myocardial infarction [38].

\section{Ocular involvement}

Common manifestations are scleritis, episcleritis and conjunctivitis [5, 39-43]. Ocular adnexal involvement in the form of periorbital edema causing proptosis or extraocular muscle palsy from vasculitis affecting the muscle or its nerve supply may be seen [5, 40, 43]. Diffuse anterior scleritis is most common, though other types of scleritis including the necrotising variant have also been reported. Uveitis is seen in up to $25 \%$ and is generally in the form of sclerouveitis or iridocyclitis [44]. Corneal involvement ranges from ulceration and thinning in $10 \%$ of patients which rarely causes perforation to severe inflammation resulting in macropannus formation or corneal melting [41, 42]. Retinopathy has been reported in $10 \%$ of patients in the series by Isaak et al. [27]. Others rarely seen are ischemic optic neuropathy [30], probably related to vasculitis, cystoids macular edema and cataract [27] which may be a result of disease activity or a complication of steroid therapy.

\section{Neurologic involvement}

Neurological manifestations from RP are related to vasculitis of the central or peripheral nervous system. These include headache, cranial neuropathies, seizures, hemiplegia, organic 
brain syndrome, aseptic meningitis, meningoencephalitis and cerebral aneurysms $[45,46]$. Optic neuropathy is the most common type of cranial nerve involvement in RP. Autopsy study in a patient with nervous system involvement by RP revealed perivascular lymphocytic infiltrate of the pia and cerebral white matter and inflammatory destruction of the myelin sheath [47].

\section{Renal involvement}

Renal involvement in RP may be a part of an associated disorder like SLE or systemic vasculitis or may be primarily due to the disease itself [48-50]. Although rare, its presence predicts a grave prognosis in RP; a 10-year survival rate of $10 \%$ has been reported [49]. Deranged creatinine levels are seen in $10 \%$ whereas an abnormal urinalysis is reported in $26 \%$ of patients with RP [49]. Renal biopsy most frequently shows a mild mesangial expansion and cellular proliferation [3]. Other findings include crescentic glomerulonephritis, glomerulosclerosis, tubular loss, IgA nephropathy and tubulointerstitial nephritis [51]. Mesangial deposits of C3, IgG or IgM are seen on immunofluorescence studies. If coexistant lupus is present, any type of lupus nephritis may be seen.

\section{Dermatological involvement}

About $35 \%$ of patients with RP alone have non-specific skin manifestations which may precede the onset of chondritis by a variable period [52]. These include purpura, papules, macules, vesicles, bullae, aphthosis, nodules over the extremities, livedo reticularis and superficial thrombophlebitis [27]. MAGIC syndrome represents a subset of patients with RP who also have features of Behcet's disease [53, 54]. Sweet syndrome has been reported as a presenting feature in a patient with RP [55]. Skin involvement is very common in patients with underlying myelodysplastic syndromes and is more frequent in males, and progresses independently of the treatment of RP [3].

\section{Systemic features}

Constitutional symptoms like fever, fatigue, weight loss and lethargy may be seen during the initial presentation and they also commonly accompany disease flares.

\section{Prognosis}

The majority of patients with RP manifest a fluctuant course with intermittent inflammatory episodes. In a given patient, the sites and severity of involvement rarely remain constant in each disease flare. Most patients experience persistent symptoms between the acute episodes. With the better management of the complications of RP, the survival has improved from 55\%at 10 years in 1986 to $94 \%$ at the end of 8 years in 1998 [3, 5]. The leading causes of mortality in these patients are lower respiratory tract infections, airway collapse, cardiac complications including valvular disease and advanced systemic vasculitis [6].

\section{Disease associations}

Concurrent autoimmune disease or less commonly, other systemic disorders are present in 25 to $35 \%$ [5] of patients with RP. The most frequent is vasculitis, seen in 12 to $18 \%$ of patients [ 3 , 5] ranges from cutaneous leukocytoclastic vasculitis to systemic vasculitis with life-threatening organ involvement. They may occur in the context of RP itself, or may be associated with primary vasculitides like polyarteritis nodosa, Wegener's granulomatosis (WG), Churg Strauss syndrome or Behcet's disease. It can affect vessels of all sizes and large vessel vasculitis is a well known complication. The latter most frequently involves the aortic ring and the ascending aorta, though the thoracic and abdominal aorta may be affected by aneurysms or rupture [56]. The various conditions that may be associated with RP besides vasculitic disorders are other autoimmune rheumatic diseases.

\section{Differential diagnosis}

Auricular chondritis can occur with trauma and infection, but sparing of the ear lobule, bilateral involvement and spontaneous remission tilt the balance in favour of RP especially in the presence of other associated features. Nasal chondritis and saddle nose needs to be differentiated from various infections, congenital syphilis, Hansen's disease and WG. When another condition is associated, the clinical picture of RP generally follows the onset of the other disease.

\section{Diagnostic criteria}

Empirical diagnostic criteria to aid the clinical diagnosis of RP were first given by McAdam et al. [5] in 1976. Damiani et al. [57] suggested an expansion of the criteria in their case series of ten patients with RP. Michet et al. [6] used a modification of this for inclusion of patients for their case series. These criteria are shown in the Table 2.

As the initial symptoms are often non-specific, the diagnosis is often missed in these stages. The mean delay from the first presentation to the time of diagnosis was estimated as 2.9 years in the series by Trentham et al. [3]. 
Table 2 Diagnostic criteria for RP

\begin{tabular}{|c|c|c|}
\hline Author & Criteria & Requiremen \\
\hline $\begin{array}{l}\text { Mc Adam } \\
\text { et al. [5]. }\end{array}$ & $\begin{array}{l}\text { Recurrent chondritis of both auricles } \\
\text { Non-erosive inflammatory polyarthritis. } \\
\text { Chondritis of nasal cartilages } \\
\text { Inflammation of auricular structures } \\
\text { (conjunctivitis/keratitis/scleritis/uveitis) } \\
\text { Chondritis of respiratory tract (laryngeal/ } \\
\text { tracheal cartilages) } \\
\text { Cochlear and/or vestibular damage } \\
\text { (neurosensory hearing loss/tinnitus/vertigo) }\end{array}$ & 3 of 6 \\
\hline $\begin{array}{l}\text { Damiani } \\
\text { et al. [57]. }\end{array}$ & $\begin{array}{l}3 \text { of } 6 \mathrm{McAdam} \text { et al. criteria } \\
1 \text { of } 6 \mathrm{McAdam} \text { et al. criteria and a positive } \\
\text { histologic confirmation } \\
2 \text { of } 6 \mathrm{McAdam} \text { et al. criteria and a } \\
\text { response to corticosteroid or dapsone }\end{array}$ & Any of these \\
\hline $\begin{array}{l}\text { Michet } \\
\text { et al. [6]. }\end{array}$ & $\begin{array}{l}\text { Proven inflammation in } 2 \text { of } 3 \text { auricular, } \\
\text { nasal or laryngotracheal cartilages } \\
\text { Proven inflammation in } 1 \text { of the above and } \\
\text { two other signs among ocular } \\
\text { inflammation, hearing loss, vestibular } \\
\text { dysfunction or seronegative } \\
\text { inflammatory arthritis }\end{array}$ & Any of these \\
\hline
\end{tabular}

\section{Investigations}

The diagnosis of RP is largely based on the clinical features and the role of laboratory investigations is purely supportive and to rule out other related or associated systemic diseases.

Blood investigations reveal elevated erythrocyte sedimentation rate and $\mathrm{C}$ reactive protein levels, normocytic normochromic anemia, leukocytosis, thrombocytosis and polyclonal hypergammaglobulinemia consistent with an inflammatory state. Urinalysis is usually normal, but patients with renal involvement manifest proteinuria or active sediments which may be accompanied by raised serum creatinine. Cerebrospinal fluid (CSF) analysis may show abnormalities in patients with CNS involvement, especially those with aseptic meningitis in whom neutrophilic pleocytosis and reduced glucose levels mimic the picture of pyogenic meningitis [58]. Anti-glutamate receptor (GluR) epsilon2 (NR2B) autoantibodies have been reported in the CSF and serum of a patient with RP and limbic encephalitis [59].

Radiographs may reveal calcification of the pinna, a nonspecific finding which may be seen with frost bite, Addison's disease, acromegaly or ochronosis. In chronic RP, the nasal and tracheal cartilage might also show calcification. Joint radiographs may reveal narrowing of the joint space due involvement of the articular cartilage, but the cysts and erosions are seen rarely [52]. Computed tomography (CT) can identify early laryngotracheal disease or bronchial cartilage involvement. In a recent series of 21 patients [60], major abnormal CT findings noted were airway wall thickening $(n=7)$, airway stenosis $(n=6)$, airway malacia $(n=6)$, airway wall calcification $(n=8)$, and air trapping $(n=3)$. Mediastinal lymph nodes were found in 12 patients. Magnetic resonance imaging or spiral CT provides better resolution and also helps to differentiate upper airway disease from vascular involvement. Virtual bronchoscopy can help in the assessment of airway lesions in patients with lung involvement [61]. Pulmonary function testing is abnormal in advanced lower respiratory tract disease. Laryngoscopy and bronchoscopy may be useful but are associated with risk of exacerbation of inflammation. Endobronchial ultrasonography can reveal soft tissue changes in the tracheobronchial cartilage in the initial stages of the disease [62]. Echocardiography is used to assess the valves and aortic root in patients with suspected cardiovascular involvement.

Histopathological examination of involved cartilage may be useful in occasional patients with diagnostic dilemma. However, no biopsy finding is pathognomonic of RP and may rather contribute to further cartilage damage. Bone scintigraphy usually reveals increased uptake of $99 \mathrm{~m}$ technetium-methylene diphosphonate in the inflamed cartilages [63] and can help locate the site of biopsy. Meticulous sampling of the inflamed perichondral tissue is required for demonstration of characteristic histologic picture, failing which only non-specific granulation tissue will be visualised [3]. The initial change is the loss of basophilia in the cartilage matrix, corresponding to loss of matrix proteoglycans. Cellular infiltrates by lymphocytes, neutrophils and plasma cells, most evident in the cartilage-soft tissue interface and reduced number of chondrocytes are seen in areas of cartilage destruction [3].

\section{Disease activity}

Anti collagen type II antibodies are generally present in the acute phase of the disease and the titres are found to correlate with disease activity [23, 64]. The level of urinary glycosaminoglycans may also be elevated [65]. The levels of urinary collagen type II neoepitope, a specific marker of catabolism of hyaline cartilage rich in type II collagen has been found to be elevated in active inflammation and can also be used to assess response to treatment [66]. Serum levels of cartilage oligomeric matrix protein was found to be elevated during disease flares in a retrospective study and may be used as a marker of disease activity [67].

The Relapsing Polychondritis Disease Activity Index (RPDAI) [68] has been developed recently by a worldwide panel of RP experts. The experts rated the Physician's Global Assessment of disease activity (the physician's evaluation of disease activity for a given test case) of the test cases involved in the study who were diagnosed with RP based on Michet's criteria. The first scoring system for disease activity 
in RP, the RPDAI will facilitate standardization of the disease activity measurement between physicians and institutions. This index, which comprises of 27 variables, is a promising step in objective clinical assessment of activity and response to treatment and is yet to be used widely in clinical trials and routine clinical practice. The online scoring is available at www.rpdai.org.

\section{Management}

Treatment in RP is largely symptomatic and a standard management protocol is yet to be established due to its rarity.

Less severe symptoms like mild auricular or nasal chondritis and arthralgia are generally treated with nonsteroid anti-inflammatory drugs. Dapsone and colchicine may also be used in these patients. Dapsone in doses of 50 to $200 \mathrm{mg}$ /day has been advocated as an effective initial therapy in patients without cardiorespiratory involvement [69-71] but Trentham et al. [3] observed that it was not effective in most patients and resulted in a number of adverse reactions. Organ-threatening disease, including severe polychondritis, ocular or laryngotracheal involvement and systemic vasculitis require systemic corticosteroids. Oral prednisolone or its equivalent is generally employed in doses of 0.5 to $1 \mathrm{mg} / \mathrm{kg}$ of body weight per day. High-dose steroid therapy or intravenous pulse therapy may be required in severe cases. Doses may be tapered off after the acute flare, but most patients require low-dose steroids in between the attacks for control of symptoms though data on this is lacking. Long-term steroid therapy may reduce the frequency and severity of the acute episodes but is not known to affect disease progression or prevent vital organ involvement [72]. Inhalational corticosteroids produce marked symptomatic relief and reduce the amount of systemic steroid requirement in patients with obstructive airway disease due to RP [73]. Oral colchicine and indomethacin have also been proved useful in the remission phase in a few reports [74].

In patients unresponsive to or more commonly intolerant to steroid therapy, or in whom a steroid sparing therapy is required due to the chronic nature of the disease, immunosuppressants play a role. Methotrexate, azathioprine, cyclosporine and chlorambucil may be used in these patients. Trentham et al. [3] observed that methotrexate was the most effective nonsteroid drug in causing symptomatic benefit and reducing the steroid requirement at an average dose of $17.5 \mathrm{mg} /$ week. Minocycline, an antibiotic with immunomodulatory actions has been used effectively in a patient who was intolerant to methotrexate [75]. Intravenous cyclophosphamide and plasmapheresis are used in patients with life-threatening or organ-threatening disease including acute airway obstruction or glomerulonephritis [48]. Letko et al. [72] report that scleritis is a marker of disease activity and advocate cyclophosphamide as the initial therapy of choice in patients with RP and necrotising scleritis. However, they observed that in patients with diffuse scleritis, methotrexate alone or in combination with steroids was sufficient. Leflunomide has been tried in some patients [7], but data regarding its safety and efficacy in RP is inadequate.

Given the autoimmune theory of etiopathogenesis of RP, a number of biologics targeting the $\mathrm{B}$ cells and the pathways of cell-mediated immunity are being used increasingly in these patients not responding to other medical therapy. Anti-CD4 monoclonal antibody was the first biological agent tried with some efficacy in RP [76, 77]. There are isolated case reports of favourable response to rituximab in patients not responding to immunosuppressive therapy $[78,79]$. However, a retrospective study [80] of 9 patients treated with rituximab showed that at the end of 12 months of therapy, no patient was in partial or complete remission though depletion of B cells was demonstrated. Anti-TNF agents have been used successfully in patients with refractory RP. AntiTNF alpha agents infliximab, adalimumab and etanercept have been used in patients not responding to conventional immunosuppression. There are several reports of infliximab (3-10 $\mathrm{mg} / \mathrm{kg}$ every 4-8 weeks) being used with good or partial response in improvement of chondritis and respiratory complications [79, 81-85]. Etanercept [86-88] and Adalimumab $[89,90]$ have been tried in a few occasions with response in some of the patients. Anakinra, the IL-1 receptor antagonist [91, 92] and Abatacept, the CTLA4IgG1 fusion protein [93] are the other agents that have been tried. Kawai et al. [94] have reported satisfactory response to anti-interleukin-6 receptor antibody, Tocilizumab in two patients with refractory relapsing polychondritis. Most evidence on the use of biologics is drawn from individual experiences and data from clinical trials is lacking. Hence, more data is required to assess the efficacy and adverse reactions of these agents and their indication is currently restricted to patients not responding to conventional medical therapy.

Patients with tracheal stricture or collapse may require stenting [95] or tracheal dilatation by interventional bronchoscopy [96]. Silicon T-tubes are an effective treatment measure for preserving airway patency in patients with tracheal stenosis due to the disease [97]. Karamen et al. [98] described surgical reconstruction of the laryngotracheal region in three patients with extensive respiratory involvement. A case of life-threatening bilateral tension pneumothorax and tension pneumoperitoneum that developed after a tracheal tear during Montgomery T-tube insertion in a patient with tracheal stenosis due to RP has been described [99]. Childs et al. [100] reported the use of pulsedpotassium-titanyl-phosphate laser for the management of bilateral bamboo nodules of the vocal folds associated with RP. Cochlear implant surgeries can restore hearing in patients with sensorineural hearing loss [101]. Reconstructive surgeries with 
grafting are a potential option for saddle nose deformity. Haug et al. [102] reported the use of a bone graft from the iliac crest, because the autoimmune polychondritis precludes cartilage grafting due to expected cartilage destruction. In patients with regurgitant lesions requiring valve replacement, recurrent perivalvular regurgitation and valve dehiscence are common due to the dilated aortic root and adjacent inflamed tissue. Sharma et al. [103] reported a case of RP in which aggressive early therapy prevented the progression of aortic regurgitation. In vivo immunoablation in combination with autologous stem cell transplant has shown to cause complete remission in a patient with refractory RP [104]. In RP associated with myelodysplastic syndrome, there are isolated case reports of both autologous and allogenic bone marrow transplant resulting in improvement of symptoms [105]. In a case report of RP associated with hepatitis $\mathrm{C}$ virus (HCV) infection, treatment with pegylated interferon and ribavirin resulted in suppression of $\mathrm{HCV}$ and remission of difficult to treat RP with azathioprine [106].

The emergence of the RPDAI consensus scoring system and the increasingly successful use of biologics are likely to have a considerable impact on the course of this relatively rare multisystem connective tissue disease.

Disclosures Aman Sharma-none; Karthik Gnanapandithan-none; Kusum Sharma — none; Susmita Sharma—none.

Funding None

\section{References}

1. Jaksch-Wartenhorst R. Polychondropathy. Wiener Archiv fur Innere Medizin 1923:93-100

2. Pearson CM, Kline HM, Newcomer VD (1960) Relapsing polychondritis. N Engl J Med 263:51-58

3. Trentham DE, Le CH (1998) Relapsing polychondritis. Ann Intern Med 129:114-122

4. Belot A, Duquesne A, Job-Deslandre C, Costedoat-Chalumeau N, Boudjemaa S, Wechsler B et al (2010) Pediatric-onset relapsing polychondritis: case series and systematic review. J Pediatr $156: 484-489$

5. McAdam LP, O'Hanlan MA, Bluestone R, Pearson CM (1976) Relapsing polychondritis: prospective study of 23 patients and a review of the literature. Med (Baltimore) 55:193-215

6. Michet CJ Jr, McKenna CH, Luthra HS, O'Fallon WM (1986) Relapsing polychondritis. Survival and predictive role of early disease manifestations. Ann Intern Med 104:74-78

7. Kong KO, Vasoo S, Tay NS, Chng HH (2003) Relapsing polychondritis - an Oriental case series. Singapore Med J 44:197-200

8. Sharma A, Bambery P, Wanchu A, Sharma YP, Panda NK, Gupta A et al (2007) Relapsing polychondritis in North India: a report of 10 patients. Scand J Rheumatol 36:462-465

9. Ananthakrishna R, Goel R, Padhan P, Mathew J, Danda D (2009) Relapsing polychondritis - case series from South India. Clin Rheumatol 28(Suppl 1):S7-S10
10. Arudell FW, Haserick JR (1960) Familial chronic atrophic polychondritis. Arch Dermatol 82:439-441

11. Papo T, Wechsler B, Bletry O, Piette AM, Godeau P, Piette JC (1997) Pregnancy in relapsing polychondritis: twenty-five pregnancies in eleven patients. Arthritis Rheum 40:1245-1249

12. Saxne T, Heinegard D (1989) Involvement of nonarticular cartilage, as demonstrated by release of a cartilage-specific protein, in rheumatoid arthritis. Arthritis Rheum 32:1080-1086

13. Buckner JH, Van Landeghen M, Kwok WW, Tsarknaridis L (2002) Identification of type II collagen peptide 261-273specific $\mathrm{T}$ cell clones in a patient with relapsing polychondritis. Arthritis Rheum 46:238-244

14. Rajapakse DA, Bywaters EG (1974) Cell-mediated immunity to cartilage proteoglycan in relapsing polychondritis. Clin Exp Immunol 16:497-502

15. Yang CL, Brinckmann J, Rui HF, Vehring KH, Lehmann H, Kekow J et al (1993) Autoantibodies to cartilage collagens in relapsing polychondritis. Arch Dermatol Res 285:245-249

16. Foidart JM, Abe S, Martin GR, Zizic TM, Barnett EV, Lawley TJ et al (1978) Antibodies to type II collagen in relapsing polychondritis. N Engl J Med 299:1203-1207

17. Giroux L, Paquin F, Guerard-Desjardins MJ, Lefaivre A (1983) Relapsing polychondritis: an autoimmune disease. Semin Arthritis Rheum 13:182-187

18. Terato K, Shimozuru Y, Katayama K, Takemitsu Y, Yamashita I, Miyatsu M et al (1990) Specificity of antibodies to type II collagen in rheumatoid arthritis. Arthritis Rheum 33:1493-1500

19. Burkhardt H, Koller T, Engstrom A, Nandakumar KS, Turnay J, Kraetsch HG et al (2002) Epitope-specific recognition of type II collagen by rheumatoid arthritis antibodies is shared with recognition by antibodies that are arthritogenic in collagen-induced arthritis in the mouse. Arthritis Rheum 46:2339-2348

20. Lang B, Rothenfusser A, Lanchbury JS, Rauh G, Breedveld FC, Urlacher A et al (1993) Susceptibility to relapsing polychondritis is associated with HLA-DR4. Arthritis Rheum 36:660-664

21. Zeuner M, Straub RH, Rauh G, Albert ED, Scholmerich J, Lang B (1997) Relapsing polychondritis: clinical and immunogenetic analysis of 62 patients. J Rheumatol 24:96-101

22. Hansson AS, Heinegard D, Piette JC, Burkhardt H, Holmdahl R (2001) The occurrence of autoantibodies to matrilin 1 reflects a tissue-specific response to cartilage of the respiratory tract in patients with relapsing polychondritis. Arthritis Rheum 44:2402-2412

23. Buckner JH, Wu JJ, Reife RA, Terato K, Eyre DR (2000) Autoreactivity against matrilin-1 in a patient with relapsing polychondritis. Arthritis Rheum 43:939-943

24. Hansson AS, Heinegard D, Holmdahl R (1999) A new animal model for relapsing polychondritis, induced by cartilage matrix protein (matrilin-1). J Clin Invest 104:589-598

25. Taneja V, Griffiths M, Behrens M, Luthra HS, David CS (2003) Auricular chondritis in NOD.DQ8.Abetao $(\mathrm{Ag} 7-/-)$ transgenic mice resembles human relapsing polychondritis. J Clin Invest 112:1843-1850

26. Sharma A, Bambery P, Wanchu A, Singh S, Panda NK (2007) A woman with abnormal ears and an unusual voice. Med J Aust 186:424

27. Isaak BL, Liesegang TJ, Michet CJ Jr (1986) Ocular and systemic findings in relapsing polychondritis. Ophthalmology 93:681-689

28. Takwoingi YM (2009) Relapsing polychondritis associated with bilateral stapes footplate fixation: a case report. J Med Case Rep 3:8496

29. Arkin CR, Masi AT (1975) Relapsing polychondritis: review of current status and case report. Semin Arthritis Rheum 5:41-62

30. Cody DT, Sones DA (1971) Relapsing polychondritis: audiovestibular manifestations. Laryngoscope 81:1208-1222

31. Gibson GJ, Davis P (1974) Respiratory complications of relapsing polychondritis. Thorax 29:726-731 
32. Mohsenifar Z, Tashkin DP, Carson SA, Bellamy PE (1982) Pulmonary function in patients with relapsing polychondritis. Chest $81: 711-717$

33. Del Rosso A, Petix NR, Pratesi M, Bini A (1997) Cardiovascular involvement in relapsing polychondritis. Semin Arthritis Rheum $26: 840-844$

34. Giordano M, Valentini G, Sodano A (1984) Relapsing polychondritis with aortic arch aneurysm and aortic arch syndrome. Rheumatol Int 4:191-193

35. Kobak S (2009) Relapsing polychondritis-associated Takayasu's arteritis. Folia Med (Plovdiv) 51:49-52

36. Balsa-Criado A, Garcia-Fernandez F, Roldan I (1987) Cardiac involvement in relapsing polychondritis. Int J Cardiol 14:381-383

37. Bowness P, Hawley IC, Morris T, Dearden A, Walport MJ (1991) Complete heart block and severe aortic incompetence in relapsing polychondritis: clinicopathologic findings. Arthritis Rheum 34:97-100

38. Dolan DL, Lemmon GB Jr, Teitelbaum SL (1966) Relapsing polychondritis. Analytical literature review and studies on pathogenesis. Am J Med 41:285-299

39. McCaffrey TV, McDonald TJ, McCaffrey LA (1978) Head and neck manifestations of relapsing polychondritis: review of 29 cases. Otolaryngology 86(3 Pt 1):ORL473-ORL478

40. Rucker CW, Ferguson RH (1965) Ocular manifestations of relapsing polychondritis. Arch Ophthalmol 73:46-48

41. Barth WF, Berson EL (1968) Relapsing polychondritis, rheumatoid arthritis and blindness. Am J Ophthalmol 66:890-896

42. Bergaust B, Abrahamsen AM (1969) Relapsing polychondritis. Report of a case presenting multiple ocular complications. Acta Ophthalmol (Copenh) 47:174-181

43. McKay DA, Watson PG, Lyne AJ (1974) Relapsing polychondritis and eye disease. Br J Ophthalmol 58:600-605

44. Matas BR (1970) Iridocyclitis associated with relapsing polychondritis. Arch Ophthalmol 84:474-476

45. Willis J, Atack EA, Kraag G (1984) Relapsing polychondritis with multifocal neurological abnormalities. Can J Neurol Sci 11:402-404

46. Pamuk ON, Harmandar F, Cakir N (2009) The development of trigeminal neuralgia related to auricular chondritis in a patient with rheumatoid arthritis-relapsing polychondritis and its treatment with etanercept. Description of the first case. Clin Exp Rheumatol 27:128-129

47. Imamura E, Yamashita H, Fukuhara T, Nagashima K, Kohriyama T, Tokinobu H (2009) Autopsy case of perivasculitic meningoencephalitis associated with relapsing polychondritis presenting with central nervous system manifestation. Rinsho Shinkeigaku 49:172-178

48. Botey A, Navasa M, del Olmo A, Montoliu J, Ferrer O, Cardesa A et al (1984) Relapsing polychondritis with segmental necrotizing glomerulonephritis. Am J Nephrol 4:375-378

49. Chang-Miller A, Okamura M, Torres VE, Michet CJ, Wagoner $\mathrm{RD}$, Donadio JV Jr et al (1987) Renal involvement in relapsing polychondritis. Med (Baltimore) 66:202-217

50. Espinoza LR, Richman A, Bocanegra T, Pina I, Vasey FB, Rifkin SI et al (1981) Immune complex-mediated renal involvement in relapsing polychondritis. Am J Med 71:181-183

51. Neild GH, Cameron JS, Lessof MH, Ogg CS, Turner DR (1978) Relapsing polychondritis with crescentic glomerulonephritis. $\mathrm{Br}$ Med J 1(6115):743-745

52. Frances C, el Rassi R, Laporte JL, Rybojad M, Papo T, Piette JC (2001) Dermatologic manifestations of relapsing polychondritis. A study of 200 cases at a single center. Med (Baltimore) 80:173-179

53. Firestein GS, Gruber HE, Weisman MH, Zvaifler NJ, Barber J, O'Duffy JD (1985) Mouth and genital ulcers with inflamed cartilage: MAGIC syndrome. Five patients with features of relapsing polychondritis and Behcet's disease. Am J Med 79:65-72

54. Orme RL, Nordlund JJ, Barich L, Brown T (1990) The MAGIC syndrome (mouth and genital ulcers with inflamed cartilage). Arch Dermatol 126:940-944
55. Wastiaux H, Hervier B, Durant C, Gagey-Caron V, Masseau A, Barbarot $\mathrm{S}$ et al (2010) Sweet's syndrome as the presenting manifestation of relapsing polychondritis. Rev Med Interne 31:e1-e3

56. Michet CJ (1990) Vasculitis and relapsing polychondritis. Rheum Dis Clin North Am 16:441-444

57. Damiani JM, Levine HL (1979) Relapsing polychondritis - report of ten cases. Laryngoscope 89(6 Pt 1):929-946

58. Yaguchi H, Tsuzaka K, Niino M, Yabe I, Sasaki H (2009) Aseptic meningitis with relapsing polychondritis mimicking bacterial meningitis. Intern Med 48:1841-1844

59. Kashihara K, Kawada S, Takahashi Y (2009) Autoantibodies to glutamate receptor GluRepsilon2 in a patient with limbic encephalitis associated with relapsing polychondritis. J Neurol Sci 287:275-277

60. Lin ZQ, Xu JR, Chen JJ, Hua XL, Zhang KB, Guan YJ (2010) Pulmonary CT findings in relapsing polychondritis. Acta Radiol 51:522-526

61. Yasutake T, Nakamoto K, Ohta A, Arai T, Wada H, Goto H (2010) Assessment of airway lesions using "virtual bronchoscopy" in a patient with relapsing polychondritis. Nihon Kokyuki Gakkai Zasshi 48:86-91

62. Miyazu Y, Miyazawa T, Kurimoto N, Iwamoto Y, Ishida A, Kanoh $\mathrm{K}$ et al (2003) Endobronchial ultrasonography in the diagnosis and treatment of relapsing polychondritis with tracheobronchial malacia. Chest 124:2393-2395

63. Imanishi Y, Mitogawa Y, Takizawa M, Konno S, Samuta H, Ohsawa A et al (1999) Relapsing polychondritis diagnosed by Tc-99m MDP bone scintigraphy. Clin Nucl Med 24:511-513

64. Alsalameh S, Mollenhauer J, Scheuplein F, Stoss H, Kalden JR, Burkhardt $\mathrm{H}$ et al (1993) Preferential cellular and humoral immune reactivities to native and denatured collagen types IX and XI in a patient with fatal relapsing polychondritis. J Rheumatol 20:1419-1424

65. Passos CO, Onofre GR, Martins RC, Graff DL, Pagani EA, Sodre $\mathrm{CT}$ et al (2002) Composition of urinary glycosaminoglycans in a patient with relapsing polychondritis. Clin Biochem 35:377-381

66. Kraus VB, Stabler T, Le ET, Saltarelli M, Allen NB (2003) Urinary type II collagen neoepitope as an outcome measure for relapsing polychondritis. Arthritis Rheum 48:2942-2948

67. Kempta Lekpa F, Piette JC, Bastuji-Garin S, Kraus VB, Stabler TV, Poole AR et al (2010) Serum cartilage oligomeric matrix protein (COMP) level is a marker of disease activity in relapsing polychondritis. Clin Exp Rheumatol 28:553-555

68. Arnaud L, Devilliers H, Peng SL, Mathian A, Costedoat-Chalumeau N, Buckner J et al (2012) The Relapsing Polychondritis Disease Activity Index: Development of a disease activity score for relapsing polychondritis. Autoimmun Rev 12:204-209

69. Barranco VP, Minor DB, Soloman H (1976) Treatment of relapsing polychondritis with dapsone. Arch Dermatol 112:1286-1288

70. Martin J, Roenigk HH, Lynch W, Tingwald FR (1976) Relapsing polychondritis treated with dapsone. Arch Dermatol 112:1272-1274

71. Ridgway HB, Hansotia PL, Schorr WF (1979) Relapsing polychondritis: unusual neurological findings and therapeutic efficacy of dapsone. Arch Dermatol 115:43-45

72. Letko E, Zafirakis P, Baltatzis S, Voudouri A, Livir-Rallatos C, Foster CS (2002) Relapsing polychondritis: a clinical review. Semin Arthritis Rheum 31:384-395

73. Tsuburai T, Suzuki M, Tsurikisawa N, Ono E, Oshikata C, Taniguchi M et al (2009) Use of inhaled fluticasone propionate to control respiratory manifestations of relapsing polychondritis. Respirology 14:299-301

74. Mark KA, Franks AG Jr (2002) Colchicine and indomethacin for the treatment of relapsing polychondritis. J Am Acad Dermatol 46(2 Suppl Case Reports):S22-S24

75. Trentham DE, Dynesius-Trentham RA (1995) Antibiotic therapy for rheumatoid arthritis. Scientific and anecdotal appraisals. Rheum Dis Clin North Am 21:817-834 
76. Choy EH, Chikanza IC, Kingsley GH, Panayi GS (1991) Chimaeric anti-CD4 monoclonal antibody for relapsing polychondritis. Lancet 338(8764):450

77. van der Lubbe PA, Miltenburg AM, Breedveld FC (1991) AntiCD4 monoclonal antibody for relapsing polychondritis. Lancet 337:1349

78. McCarthy EM, Cunnane G (2010) Treatment of relapsing polychondritis in the era of biological agents. Rheumatol Int 30:827-828

79. Ratzinger G, Kuen-Spiegl M, Sepp N (2009) Successful treatment of recalcitrant relapsing polychondritis with monoclonal antibodies. J Eur Acad Dermatol Venereol 23:474-475

80. Leroux G, Costedoat-Chalumeau N, Brihaye B, Cohen-Bittan J, Amoura Z, Haroche J et al (2009) Treatment of relapsing polychondritis with rituximab: a retrospective study of nine patients. Arthritis Rheum 61:577-582

81. Mpofu S, Estrach C, Curtis J, Moots RJ (2003) Treatment of respiratory complications in recalcitrant relapsing polychondritis with infliximab. Rheumatology (Oxford) 42:1117-1118

82. Saadoun D, Deslandre CJ, Allanore Y, Pham XV, Kahan A (2003) Sustained response to infliximab in 2 patients with refractory relapsing polychondritis. J Rheumatol 30:1394-1395

83. Jabbarvand M, Fard MA (2010) Infliximab in a patient with refractory necrotizing scleritis associated with relapsing polychondritis. Ocul Immunol Inflamm 18:216-217

84. Marie I, Lahaxe L, Josse S, Levesque H (2009) Sustained response to infliximab in a patient with relapsing polychondritis with aortic involvement. Rheumatology (Oxford) 48:1328-1329

85. Richez C, Dumoulin C, Coutouly X, Schaeverbeke T (2004) Successful treatment of relapsing polychondritis with infliximab. Clin Exp Rheumatol 22:629-631

86. Schrader C, Lohmann J (2010) Successful therapy with etanercept in relapsing polychondritis. Z Rheumatol 69:356-358

87. Subrahmanyam P, Balakrishnan C, Dasgupta B (2008) Sustained response to etanercept after failing infliximab, in a patient with relapsing polychondritis with tracheomalacia. Scand J Rheumatol 37:239-240

88. Carter JD (2005) Treatment of relapsing polychondritis with a TNF antagonist. J Rheumatol 32:1413

89. Seymour MW, Home DM, Williams RO, Allard SA (2007) Prolonged response to anti-tumour necrosis factor treatment with adalimumab (Humira) in relapsing polychondritis complicated by aortitis. Rheumatology (Oxford) 46:1738-1739

90. Lahmer T, Knopf A, Treiber M, Heemann U, Thuermel K (2010) Treatment of relapsing polychondritis with the TNF-alpha antagonist adalimumab. Clin Rheumatol 29:1331-1334

91. Vounotrypidis P, Sakellariou GT, Zisopoulos D, Berberidis C (2006) Refractory relapsing polychondritis: rapid and sustained response in the treatment with an IL-1 receptor antagonist (anakinra). Rheumatology (Oxford) 45:491-492
92. Buonuomo PS, Bracaglia C, Campana A, El Hachem M, Diociaiuti A, Insalaco A et al (2010) Relapsing polychondritis: new therapeutic strategies with biological agents. Rheumatol Int 30:691-693

93. Moulis G, Sailler L, Astudillo L, Arlet P (2010) Abatacept for relapsing polychondritis. Rheumatology (Oxford) 49:1019

94. Kawai M, Hagihara K, Hirano T, Shima Y, Kuwahara Y, Arimitsu J et al (2009) Sustained response to tocilizumab, anti-interleukin-6 receptor antibody, in two patients with refractory relapsing polychondritis. Rheumatology (Oxford) 48:318-319

95. Butt S, Munch EP (2010) Relapsing polychondritis. Ugeskr Laeger 172:714-716

96. Mendez-Flores S, Vera-Lastra O, Osnaya-Juarez J (2009) Tracheal stenosis as a initial manifestation of relapsing polychondritis. Case report. Rev Med Inst Mex Seguro Soc 47:673-676

97. Nakayama T, Horinouchi H, Asakura K, Ohtsuka T, Izumi Y, Kohno $M$ et al (2011) Tracheal stenosis due to relapsing polychondritis managed for 16 years with a silicon T-tube covering the entire trachea. Ann Thorac Surg 92:1126-1128

98. Karaman E, Duman C, Cansz H, Ylmaz M, Ibrahimov M (2010) Laryngotracheal reconstruction at relapsing polychondritis. J Craniofac Surg 21:211-212

99. Lin YT, Zuo Z, Lo PH, Hseu SS, Chang WK, Chan KH et al (2009) Bilateral tension pneumothorax and tension pneumoperitoneum secondary to tracheal tear in a patient with relapsing polychondritis. J Chin Med Assoc 72:488-491

100. Childs LF, Rickert S, Wengerman OC, Lebovics R, Blitzer A (2012) Laryngeal manifestations of relapsing polychondritis and a novel treatment option. J Voice 26:587-589

101. Seo YJ, Choi JY, Kim SH, Kim TJ (2012) Cochlear implantation in a bilateral sensorineural hearing loss patient with relapsing polychondritis. Rheumatol Int 32:479-482

102. Haug MD, Witt P, Kalbermatten FD, Rieger UM, Schaefer DJ, Pierer G (2009) Severe respiratory dysfunction in a patient with relapsing polychondritis: should we treat the saddle nose deformity? J Plast Reconstr Aesthet Surg 62:e7-e10

103. Sharma A, Mittal T, Kumar S, Law AD, Wanchu A, Mahajan R et al (2010) Successful treatment of aortic root dilatation in a patient with relapsing polychondritis. Clin Rheumatol 32(Suppl 1):S59-S61

104. Rosen O, Thiel A, Massenkeil G, Hiepe F, Haupl T, Radtke H et al (2000) Autologous stem-cell transplantation in refractory autoimmune diseases after in vivo immunoablation and ex vivo depletion of mononuclear cells. Arthritis Res 2:327-336

105. Tomomatsu J, Hamano Y, Ando J, Komatsu N, Sugimoto K (2012) Non-myeloablative allogenic BMT for myelodysplastic syndrome successfully controlled accompanying relapsing polychondritis. Bone Marrow Transplant 47:742-743

106. Hemmati I, Yoshida E, Shojania K (2012) Relapsing polychondritis associated with hepatitis C virus infection. Clin Rheumatol 31:391-394 